Article

\title{
Analysis of Power Bank Quality Criteria That Are Important from the Consumer's Point of View
}

\author{
Jacek Czerniak*(D), Anna Gacek (D) and Przemysław Szopa (D)
}

check for updates

Citation: Czerniak, J.; Gacek, A.; Szopa, P. Analysis of Power Bank Quality Criteria That Are Important from the Consumer's Point of View. Energies 2021, 14, 5747. https:// doi.org/10.3390/en14185747

Academic Editor: Carlos Miguel Costa

Received: 16 July 2021

Accepted: 7 September 2021

Published: 13 September 2021

Publisher's Note: MDPI stays neutral with regard to jurisdictional claims in published maps and institutional affiliations.

Copyright: (c) 2021 by the authors. Licensee MDPI, Basel, Switzerland. This article is an open access article distributed under the terms and conditions of the Creative Commons Attribution (CC BY) license (https:/ / creativecommons.org/licenses/by/ $4.0 /)$.
Department of Metrology and Instrumental Analysis, Institute of Quality Sciences and Product Management, College of Management and Quality Sciences, Cracow University of Economics, 31-510 Kraków, Poland; gaceka@uek.krakow.pl (A.G.); szopap@uek.krakow.pl (P.S.)

* Correspondence: czerniaj@uek.krakow.pl

\begin{abstract}
Consumers of mobile devices expect manufacturers to produce devices that will be an efficient source of electric energy. The batteries currently used in smartphones allow the devices to operate for several hours. Power banks extend the operating time of the device without the need to charge via a charger connected to the mains. The present paper defines first the features of power banks that are the most important for users and, moreover, what knowledge or opinions about important power bank features customers use during purchase. As shown in the survey, according to the respondents, the most important feature determining the quality of a power bank is its capacity. It has been shown in this research that the actual capacity of a power bank is circa $2 / 3$ of the capacity indicated. What have also been investigated are the differences between the average capacities of power banks with Li-ion batteries and the technologically newer Li-Po batteries, in favor of the latter. Power banks were not differentiated according to the type of battery and charging times in the standard variant, with a voltage of $5 \mathrm{~V}$. It has been shown that the smaller usable capacity of the power bank does not affect the faster charging time.
\end{abstract}

Keywords: power banks; quality; accumulators; Li-ion; Li-Po

\section{Introduction}

The second decade of the 21st century was characterized by the development of mobile technologies based on devices requiring significant energy resources available without the need for frequent recharging from stationary sources. Reports [1,2] have shown that in $2018,66 \%$ of the world's population had a mobile device in the form of a smartphone, while according to the Mobirank report [3], in 2020, already approx. 67\% of the world's population used a smartphone. In addition, the time spent on the internet during the day per user of devices connected to the internet in the age range of 16-64 increases year over year [4-6]. According to the GlobalWebIndex report, in 2019, the world average of the time spent on the web per person was $6 \mathrm{~h}$ and $43 \mathrm{~min}$. The citizens of the Philippines spent the most time online, almost $10 \mathrm{~h}$ a day, while the least time online was spent by Japanese citizens, where the time spent online was less than $4.5 \mathrm{~h}$ a day. According to 2019 data, more than $50 \%$ of this time was spent on mobile devices such as tablets, smartphones, or smartwatches. There is a clear trend in the world to shift an increasing part of social life online. Continuous web activity requires devices that will remain operational for as long as possible. Users of mobile devices expect manufacturers to produce devices that will be characterized by reliability, modern design, low weight, and an efficient source of electric energy. Meeting all these requirements is extremely difficult, especially with regard to the battery and the weight associated with it. Currently produced mobile devices, such as smartphones, require batteries with large capacities, often exceeding $4000 \mathrm{mAh}$, due to the increasingly more technologically advanced solutions regarding, among others, the processor or display. The batteries currently used by smartphone manufacturers allow for uninterrupted operation of the devices for several hours during maximum load. Taking into 
account the current lifestyle of societies in developed countries, where access to information is required regardless of time and place, an additional source of energy in the form of a power bank will extend the operating time of the device without the need to charge via a charger connected to the mains. With the technological development of mobile devices, consumer demands on portable energy sources are growing and are not limited to the amount of useful and usable stored electric energy.

\section{Quality Criteria of Power Banks}

Ensuring the proper functionality of the device is essential, which is why power banks must meet strict quality and safety criteria. Detailed inspection of the power bank helps to verify whether the products meet the manufacturers' marketing promises. It often turns out that the parameters of the device shown on the casing or packaging do not correspond to the parameters of the power bank expected by customers. The basic areas in which verification and quality control should be carried out include the following evaluation elements:

Correctness of workmanship: the surface of the product should not have any visible defects (dirt stains, scratches, etc.);

Voltage and current intensity tests;

Charge and discharge tests;

Checking the tolerances of dimensions and weight;

Basic tests of the power bank functions (e.g., correct operation of moving parts, such as buttons);

Aging tests;

Tests of the capacity of cells constituting the power bank battery;

Tests of resistance to damage during normal use of the product,

Estimation of the recycling rate of used power banks, particularly the battery cells.

The quality control of a power bank begins with a visual inspection of the device and all of its components, including product dimensions, internal wiring, batteries, charging ports, manufacturer's logo and brand information, USB cables, and LEDs as a charge indicator. The quality assessment of the device includes all measurements of electrical parameters of the power bank. One of the most important parameters, from the point of view of a potential user, is the efficient operation of the charging function. Currently (2021), manufacturers put emphasis on the production of power banks, the charging of which takes as little time as possible in relation to the declared rated capacity of the power bank. The current fast charging systems use technologies included in the following standards: Qualcomm Quick Charge, Apple Fast Charge, Motorola Turbo Power, Dash Charge, and the latest and the fastest of all, Oppo Super VOOC standard, all of which are available for charging batteries in smartphones. These standards differ slightly from each other and offer various charging modes. Accelerated charging of the cells that make up the power bank may deteriorate the parameters of the nominal capacity. Therefore, it is extremely important to apply solutions that will ensure that the standard used is safe, which means that its use should not have a negative impact on battery life. The feature indicating a high quality of the purchased power bank is its versatility, e.g., equipment with several USB ports of different types, allowing one to power several devices that differ technologically due to the input ports used. The most universal power banks are equipped with the three most commonly used USB input standards, i.e., USB-A, micro-B USB, and the latest USB type C. The latest standards of fast charging also require the use of new USB input standards in power banks. In order to check the usability of the USB input standards used, as part of quality control, power banks are subjected to rigorous tests to determine, among others, the maximum usable output voltage, its stabilization as a function of changing load, and output power. Highly important criteria with regard to the efficiency of power banks are the multiple charging and discharging tests, which allow for averaging the actual capacity of the power bank that can accumulate useful electric energy. In addition, power 
banks should be equipped with intelligent protections to avoid problems with overvoltage, overcharging, overheating, short-circuit, and over-discharge.

Carrying out a wide range of electrical tests for power banks allows one to determine their actual parameters, which is an important quality criterion for a potential user. The consumer purchasing the product should be assured by the manufacturer not only about its operational parameters, but also about the compliance of the device with the requirements contained in the declaration of conformity, which is a document issued during CE (Conformité Européenne) marking. The declaration of conformity together with the assigned CE mark certifies that the manufacturer was aware of their obligations under the currently applicable law and duly fulfilled them to the extent that allows them to state that the product is safe to use. Power banks, as electrical devices, are subject to the provisions of the EMC Directive 2014/30/EU and the Directive on hazardous substances contained in electrical and electronic equipment 2011/65/EU [7,8]. Every entrepreneur importing and introducing to the European Union market electrical equipment, including power banks, which has not been CE-marked, risks being condemned to pay a high fine (up to PLN 20,000 for the lack of the CE mark, and up to PLN 100,000 for placing on the market or putting to use a noncompliant product [9]). In addition, in the event that a noncertified power bank overheats or catches fire, which will be a direct cause of damage to the health of the person using the product, the entrepreneur may be obliged by the court to pay a high compensation. As with any consumer electronics, defective power banks can pose a risk to customers and damage other equipment if not properly tested for safe use.

In addition to ensuring the safety of use, manufacturers are increasingly launching power banks that can be used in hostile environments, such as rain, fog, and strong air dust. The functionality of the power bank under such demanding conditions requires compliance with standards indicating IP44 waterproofness, IP67 dustproofness, as well as shock resistance in accordance with the military standard MIL-STD 810F 516.5 for products used by services such as the police or the army [10].

Meeting the above quality requirements can significantly extend the life of the power bank; however, as with any electrical device, it is subject to wear and disposal at the final stage of its life cycle. The degree of recovery of the power bank components also indicates that the device has been produced in accordance with current trends, the so-called Circular Economy. The circular economy model is based on the assumption that products, materials, and resources are to be kept in use for as long as possible, and ultimately, waste generation should be reduced to a minimum [11]. It is therefore necessary to manufacture power banks that will follow as closely as possible the European Union's guidelines regarding quality standards for secondary raw materials, the development of eco-design, the possibility of repair and re-introduction to the market, as well as possible full recycling or recovery. In European and North American countries, the batteries, which are essential components of each power bank, are considered hazardous waste due to toxic spills, and are subject to industrial disposal [12]. The recycling of used power banks will be a significant problem in the near future because of the increasing global market for portable energy sources. Consumers often underestimate the issues related to the end-of-life stage of products, paying excessive attention to the performance parameters of the devices they use.

\section{Materials and Methods}

As far as the type of cells used is concerned, modern power banks may have a lithiumion or polymer battery. Lithium-ion (Li-ion) batteries consist of several basic elements, i.e., cathode, anode, electrolyte, and separator [13]. The cathode is the part of the cell that is the source of lithium ions and that also determines the voltage and capacity of the battery. The anode allows current to flow and stores ions during the charging process. The electrolyte is the medium through which lithium ions can be conducted from the cathode to the anode, while the separator is a physical barrier between the anode and the cathode. Currently produced Li-ion cells are characterized by a much higher energy density compared to older types of cells, which directly translates into an increase in their capacity and efficiency. The 
shape of Li-ion batteries in most of the currently manufactured devices is cylindrical, and they are produced less frequently in the shape of rectangular prisms [14,15].

Lithium-polymer (Li-Po) batteries can achieve considerable energy capacity. However, they are much more likely to be damaged by deep discharge, when the cell voltage drops below $3 \mathrm{~V}$. To prevent this negative effect, most modern Li-Po cells are equipped with an additional safety circuit that disconnects the cell from the receiver when the voltage drops to the threshold value of the order of $3 \mathrm{~V}$ [16-18]. Such a solution increases the scope of implementation of polymer cells in relation to Li-ion cells in power bank devices. Polymer cells are characterized by a low self-discharge current compared to Li-ion cells. The low self-discharge rate allows the use of polymer cells where it is required to power electronics for many hours or days without the need for recharging.

The present paper defines first the features of power banks that are the most important for users and, moreover, what knowledge or opinions about important power bank features customers use during purchase. The respondents assessed power banks in terms of selected physical properties, usability, technology used (chemical structure of the battery), visual aspects, price, and opinions of other consumers about the product. The aims of the data collected using the questionnaire were as follows: (I) determining the preferences consumers follow when buying power banks, (II) examining their awareness of the differences between various types of batteries in the power bank, and (III) checking the state of customers' knowledge regarding the differences in selected electrical parameters between their actual values and those given on the power bank packaging. In the second stage, the properties of power banks, important from the point of view of the consumer, were verified using electrical tests. (I) The capacity and stored energy of the products tested were determined under actual standard conditions of use (discharge); (II) the average capacities of power banks with two types of batteries: Li-ion and Li-Po, were compared; (III) the capacities of power banks were checked under quick discharge conditions; (IV) the charging times of power banks themselves were determined; $(\mathrm{V})$ the mass of each product was determined; and (VI) the parameter defining the relationship between the real capacity and the weight of each power bank was calculated.

\section{Research Methodology}

A questionnaire survey was conducted with 309 respondents aged up to 30 (Table 1). The data collected was subject to quantitative analysis in the STATISTICA program (StatSoft, Palo Alto, CA, USA). One-way analysis of variance (ANOVA) was used to compare the results between the different quality criteria. The significance of differences between the means was assessed post hoc with the Fischer LSD test. In the statistical analyses performed, the level of $p<0.05$ was considered significant.

Table 1. Demography for the study.

\begin{tabular}{ccccc}
\hline Sample Size & Age (Years) & Male & Female & Place of Origin \\
\hline 309 & $\leq 30$ & $58 \%$ & $42 \%$ & $\begin{array}{c}\text { Village (8\%), Semi-urban (16\%), } \\
\text { Urban }(76 \%)\end{array}$ \\
\hline
\end{tabular}

Electrical tests were carried out on power banks of 10 manufacturers. From among the power banks available on the market, those with a capacity of 10,000 mAh declared by the manufacturers were selected (Duracell says 10,050 mAh). Products with both Li-ion and Li-Po batteries were selected (Table 2).

A microprocessor device was used for the tests, which allowed the discharging of the tested power banks with any preset current, including simulating a high-rate discharge of the power bank (quick charging of the target device). The microprocessor device also allowed the monitoring of the charging of power banks. It was calibrated using an AXIO MET AX-18B digital multimeter. The power banks tested were discharged in a climatic chamber at a constant temperature $\mathrm{T}=21.5^{\circ} \mathrm{C}\left(\Delta \mathrm{T}=0.5^{\circ} \mathrm{C}\right)$ and air humidity ranging from $35 \%$ to $55 \%$. 
Table 2. Power bank devices for the study.

\begin{tabular}{ccc}
\hline Manufacturer & Declared Capacity $(\mathbf{m A h})$ & Battery Type \\
\hline Belkin & 10,000 & Li-ion \\
\hline Duracell & 10,050 & Li-ion \\
\hline Green Cell (GC) & 10,000 & Li-Po \\
\hline GP & 10,000 & Li-ion \\
\hline Hama & 10,000 & Li-Po \\
\hline Huawei & 10,000 & Li-ion \\
\hline Intenso & 10,000 & Li-Po \\
\hline Platinet & 10,000 & Li-Po \\
\hline Samsung & 10,000 & Li-ion \\
\hline TP-Link & 10,000 & Li-Po
\end{tabular}

In the statistical analyses of electrical parameters, the following methods of the evaluation of measurement uncertainties were used: type A (based on statistical analysis of a series of measurement results) and type B (based on the probability distribution adopted in the study). The standard uncertainty for a series of measurements, calculated using method $\mathrm{A}$, is equal to the standard deviation of the mean. This method was applied with the assumption that the probability of occurrence of the results lower and higher than the mean is the same. Method B was used when the variance $\mathrm{u} 2$ (xi) of the input quantity could not be determined based on repeated observations or there was no scattering of results.

\section{Survey on Power Banks}

The survey questions concerned the most important features of the power bank, which, in the opinion of the respondents, determine its quality. The respondents were asked to use a score on a scale from 1 to 5 , where 1 is a feature of little importance for the quality of the power bank, and 5 is a feature that is very important. The answers to these questions are summarized in the form of a column chart and presented in Figure 1.

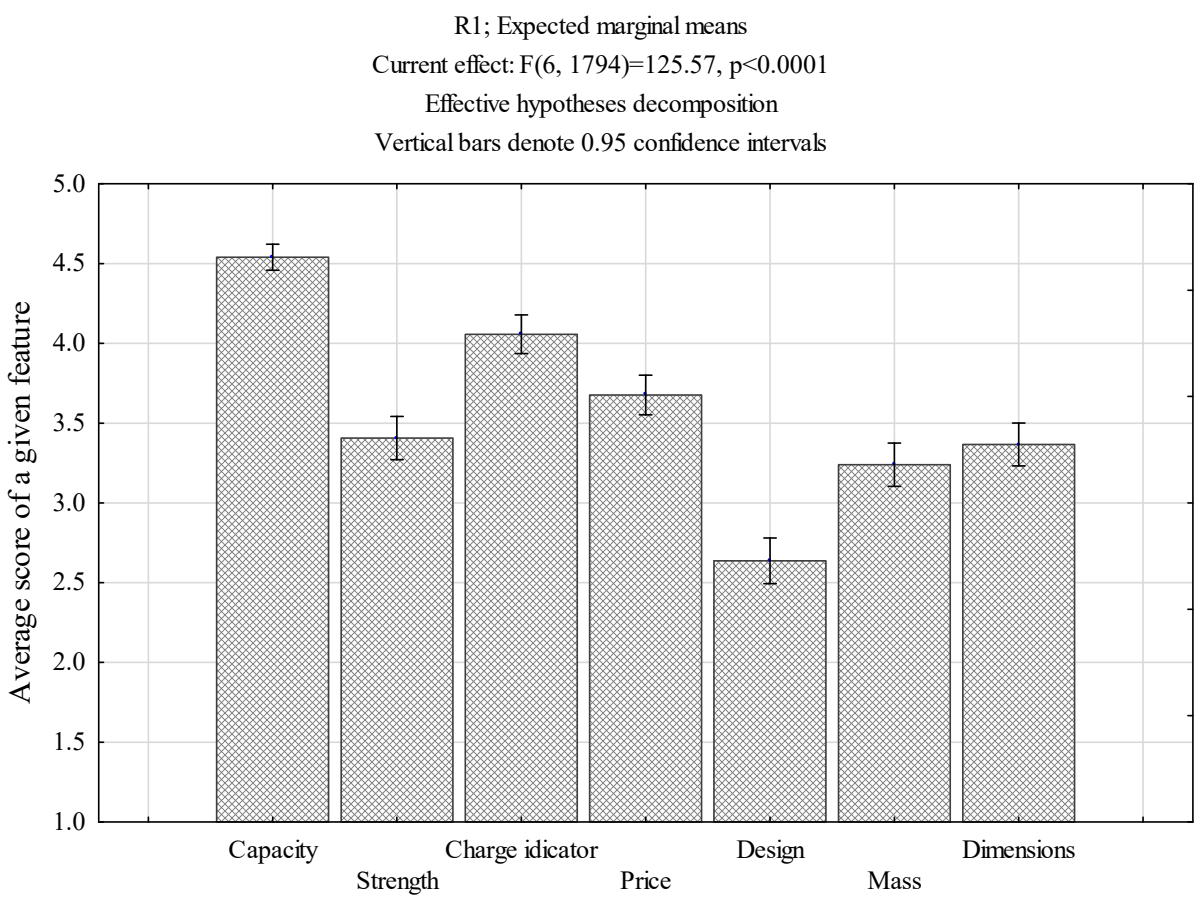

Figure 1. The most important features of a good power bank as indicated by respondents. 
The main effects of the analysis of variance presented in the column chart (Figure 1) are statistically significant with $F(6,1794)=125.57, p<0.0001$. A statistically significant difference was demonstrated between almost all criteria. The following were undifferentiated in relation to each other: strength, weight, and dimensions, i.e., the size of the power bank (Appendix A). As shown by the results of this part of the survey, according to the respondents, the most important feature determining the quality of a power bank is its capacity. As the second determinant of quality, the respondents indicated that the power bank should be equipped with charging indicators, while the price of the product was the third criterion. The respondents placed in fourth place such features as strength, weight, and dimensions of the power bank. The design of the device turned out to be the least important quality criterion. The second question of the survey concerned the criteria used by the respondents when buying a power bank. The test results are presented in the column chart (Figure 2). To keep the chart clear, the features have been encoded in capital letters and the legend has been placed below the chart.

R1; Expected marginal means

Current effect: $F(9,2673)=174.41, p<0.0001$

Effective hypotheses decomposition

Vertical bars denote 0.95 confidence intervals

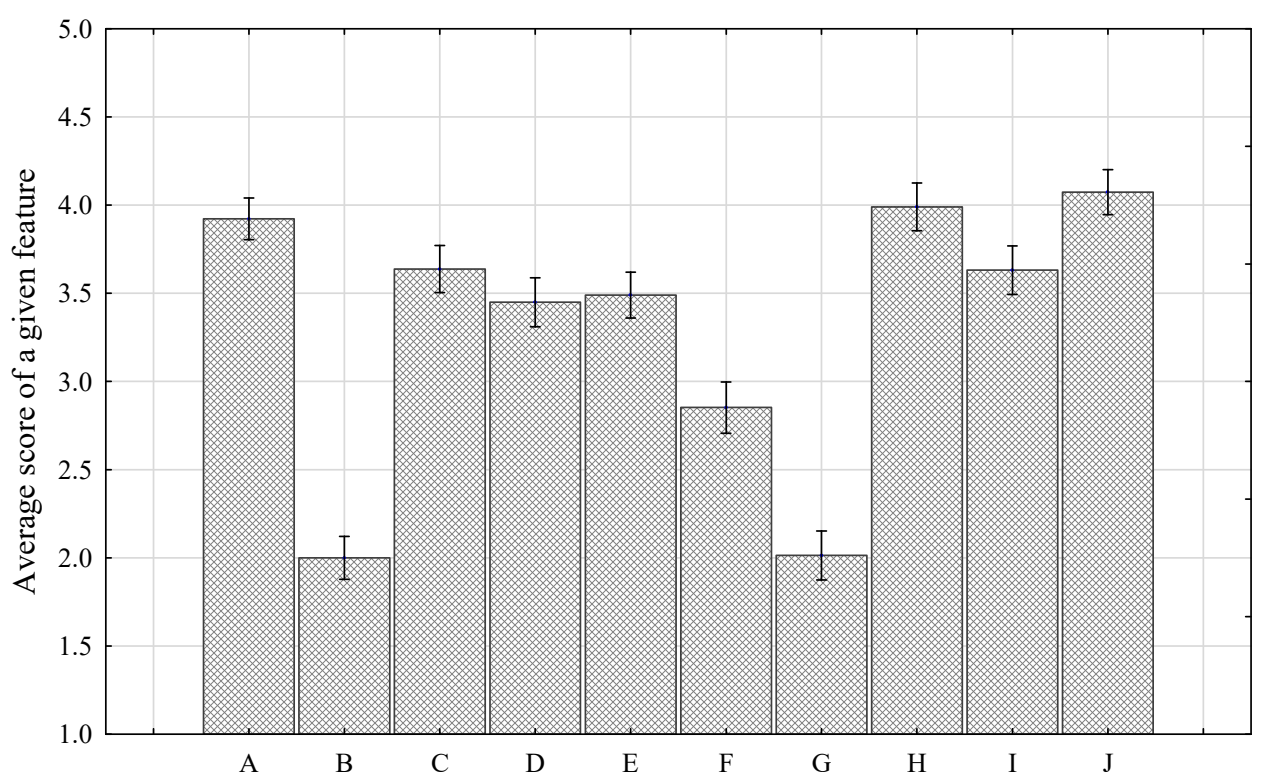

Figure 2. The most important criteria the respondents follow when buying a power bank (A-Price, B-Product appearance in advertisements, C-Opinions of other users, D-Opinions on online forums, E-Availability, F-Information on the packaging, G-Additional functions of power bank, e.g., built-in flashlight, $\mathrm{H}-$ Feature of quick charging of target devices, I-Possibility of simultaneous charging of multiple devices, J-Feature of quick charging of the power bank).

The main effects of the analysis of variance presented in the column chart (Figure 2) are statistically significant with $\mathrm{F}(9,2673)=174.41, p<0.0001$ (Appendix B). The main determinants that customers follow when buying a power bank are the price, quick charging functions for devices from the power bank, and the quick charging function of the power bank itself. It was confirmed that the above-mentioned features do not show significant statistical differences, so it can be concluded that they are all equally important. Ranked lower in terms of importance are the opinions of other users, opinions that can be read on the internet, the ability to charge multiple devices at the same time, and finally the availability of a power bank. As with the previously mentioned criteria, there are no statistical differences between them. The third most important element was the information on the packaging, while the last element determining the choice of a power bank was additional functions, such as a built-in flashlight and the appearance of these products 
in advertisements. A statistically significant differentiation between some criteria was demonstrated.

As power banks available on the domestic market differ in the type of cells used in their construction, the respondents were asked a question checking their awareness regarding this aspect. The respondents were asked about the differences between power banks equipped with lithium-ion batteries and those with lithium-polymer batteries. In this case, five answers were proposed (Yes, Rather yes, I don't know, Rather no, and No), and the results are summarized in the form of a pie chart (Figure 3).

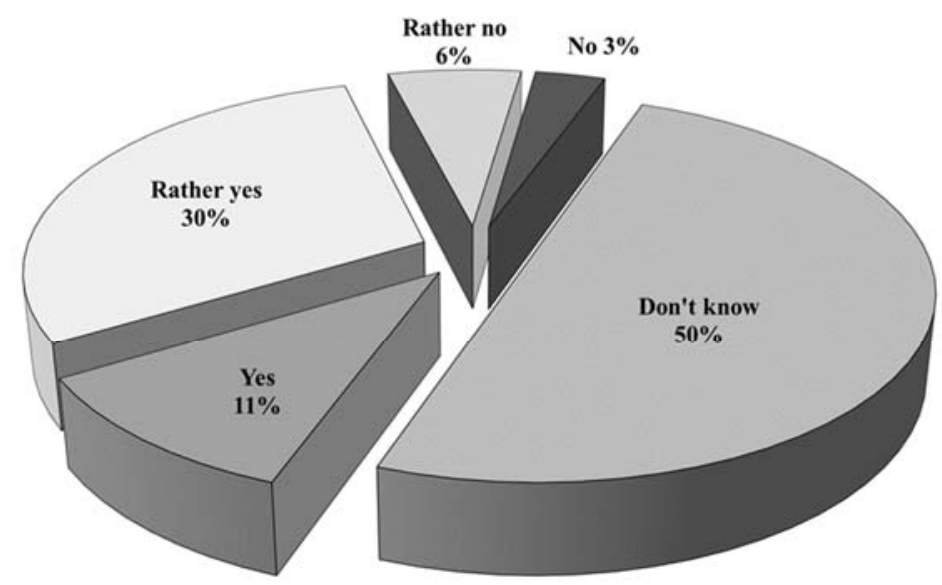

Figure 3. Answers to the question about the differences between power banks equipped with lithium-ion and lithium-polymer batteries.

The answers to this question indicate that $50 \%$ of respondents cannot say whether there are differences between the two types of power banks. The analysis shows that $41 \%$ of respondents believe that such differences exist, and $9 \%$ believe that there are no such differences. Another question put to the respondents in this survey concerned the capacity of power banks, i.e., whether, in their opinion, the actual capacity differed from that declared on the packaging. After analyzing the answers, it can be concluded that nearly half of the respondents (48\%) believe that the capacity described on the power bank packaging and the actual capacity do not coincide (Figure 4).

In the survey, the respondents were also asked the question: "Will the higher price of the power bank correlate positively with its quality?" The answers to this question are presented in Figure 5. Over 60\% of the respondents answered yes to this question.

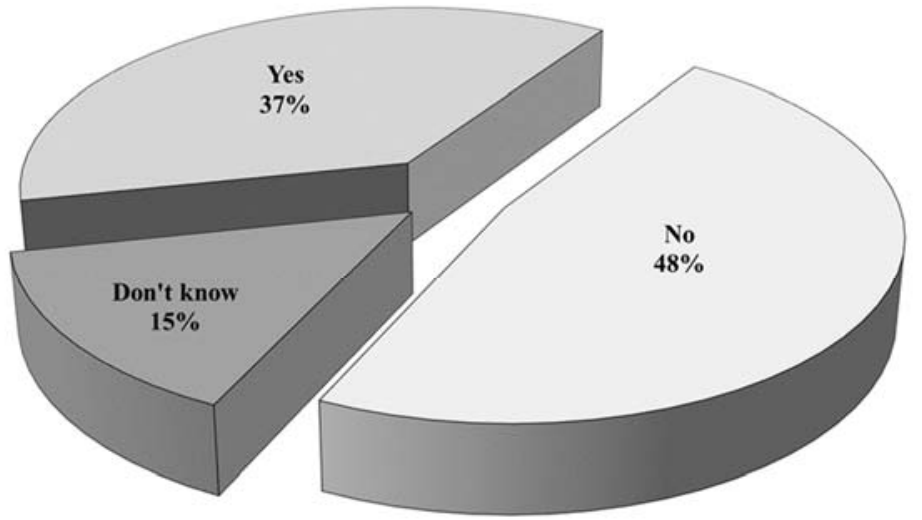

Figure 4. Answers to the question about the relationship between the actual (rated) capacity and the capacity declared on the power bank packaging. 


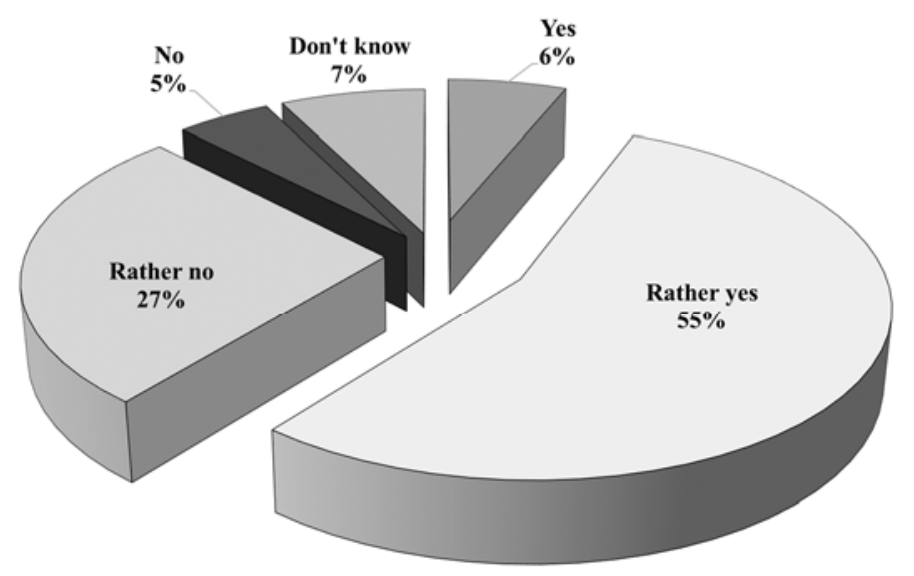

Figure 5. Respondents' answers regarding the correlation between the price and the quality of power banks offered on the market.

\section{Tests of Electric Parameters of Power Banks}

The most important criterion determining the quality of the power bank, in the opinion of the respondents, is its capacity. Most power banks, including all those covered by the present study, have an output voltage of $5 \mathrm{~V}$, which allows one to charge almost all mobile devices, such as smartphones, iPods, e-book readers, headphones, gamepads, tablets, sports cameras, and digital cameras. Therefore, the first test carried out concerns the comparison of the capacity measured in the standard discharge mode with the current $\mathrm{I}=1 \mathrm{~A}$ and the voltage $\mathrm{U}=5 \mathrm{~V}$, with the capacity declared by the manufacturer (Table 3 ). The results of capacity measurements for each brand of power banks, as presented in the table below, were obtained on the basis of the average of 7 measurements for each power bank. The standard uncertainty uA was also determined for each of the measurements, ranging from $14 \mathrm{mAh}$ to $50 \mathrm{mAh}$.

Table 3. Capacities of tested power banks.

\begin{tabular}{ccc}
\hline Power Bank Manufacturer & $\begin{array}{c}\text { Capacity Measured for Discharging } \\
\text { with 1 A Current at 5 V Voltage, mAh }\end{array}$ & Measurement Uncertainty, mAh \\
\hline Belkin & 6575 & 30 \\
\hline Duracell & 6499 & 54 \\
\hline GC & 7068 & 39 \\
\hline GP & 6690 & 41 \\
\hline Hama & 7488 & 40 \\
\hline Huawei & 6783 & 38 \\
\hline Intenso & 7344 & 40 \\
\hline Platinet & 6961 & 14 \\
\hline Samsung & 6940 & 26 \\
\hline TP-Link & 6961 & \\
\hline
\end{tabular}

The results of the tests show the capacitive parameters of power banks and the discrepancy between the values declared by the manufacturers and those resulting from the standard use of power banks, i.e., with the above-mentioned current-voltage parameters. These differences are visible for all brands of power banks. Manufacturers' declarations result from the capacity calculated for discharging at a voltage of $3.7 \mathrm{~V}$. Some manufacturers provided this most important information for the consumer about the power bank capacity for the output voltage of $5 \mathrm{~V}$ on the packaging of their products (Platinet and Samsung), but they were in a significant minority. A $10,000 \mathrm{mAh}$ battery is one that, at a certain 
voltage, can theoretically deliver, e.g., a current of $1 \mathrm{~A}$ for ten hours or a current of $2 \mathrm{~A}$ for five hours. In fact, the current is limited by the transmission capacity of the USB connector. The current limits are given by the manufacturer in the device specification. Lithium-ion and lithium-polymer batteries supply the greatest energy at a voltage of $3.7 \mathrm{~V}$. Thus, the total energy of a battery with a capacity of $10,000 \mathrm{mAh}$ is $37 \mathrm{Wh}$.

As in the case of capacity measurements, the results of the tests carried out for the total energy of power banks show discrepancies in relation to the values declared by manufacturers, and they are visible for all brands of power banks (Figure 6). The results of the total energy measurements of the power banks of each brand presented in the chart below were obtained for a standard power bank discharge with the following parameters: $\mathrm{I}=1 \mathrm{~A}$ and $\mathrm{U}=5 \mathrm{~V}$.

Comparison of stored energy of power banks - declared vs. measured for $1 \mathrm{~A} / 5 \mathrm{~V}$ discharge, Wh

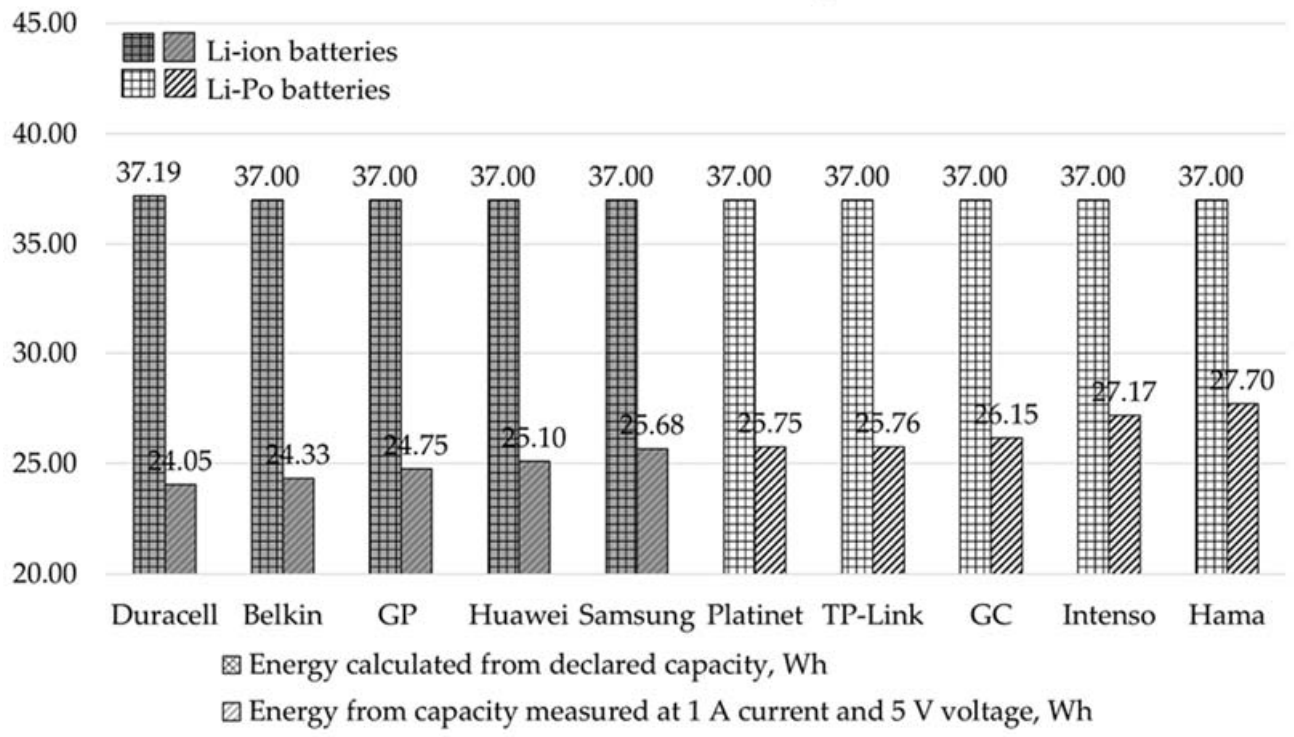

Figure 6. Results of measurements of the total energy of power banks with Li-ion and Li-Po batteries.

A percentage of $50 \%$ of the respondents could not say whether there were differences between $\mathrm{Li}$-ion and $\mathrm{Li}$-Po batteries. It can be concluded from the above studies that LiPo batteries, compared to Li-ion batteries, generally have a higher real capacity. This hypothesis was tested using the LSD-Fischer test (Figure 7).

The main effects of the analysis of variance presented in the column chart (Figure 8) are statistically significant with $\mathrm{F}(9,54)=94.617, p<0.0001$.

The power banks tested belong to two groups, equipped with Li-ion and Li-Po batteries. The first five brands are Li-ion power banks, and the other five of the tested power banks are equipped with Li-Po batteries. In the former group, only the Samsung power bank does not show statistical differences compared to the power banks equipped with Li-Po batteries. The chart also shows a clear advantage of Hama and Intenso (Li-Po) power banks over other brands. In order to check the statistical significance of the differences between the brands studied, the LSD-Fischer test was carried out. Statistical significance was confirmed for almost all tested cases, except for Belkin and Duracell power banks (both with Li-ion batteries), Samsung and Platinet (the former with a Li-ion battery, the latter with Li-Po), and TP-Link and Platinet (both with Li-Po batteries). The average capacity for the group of five Li-ion power banks is $6697 \mathrm{mAh}$, while for the group of five Li-Po power banks, it is $7164 \mathrm{mAh}$. 


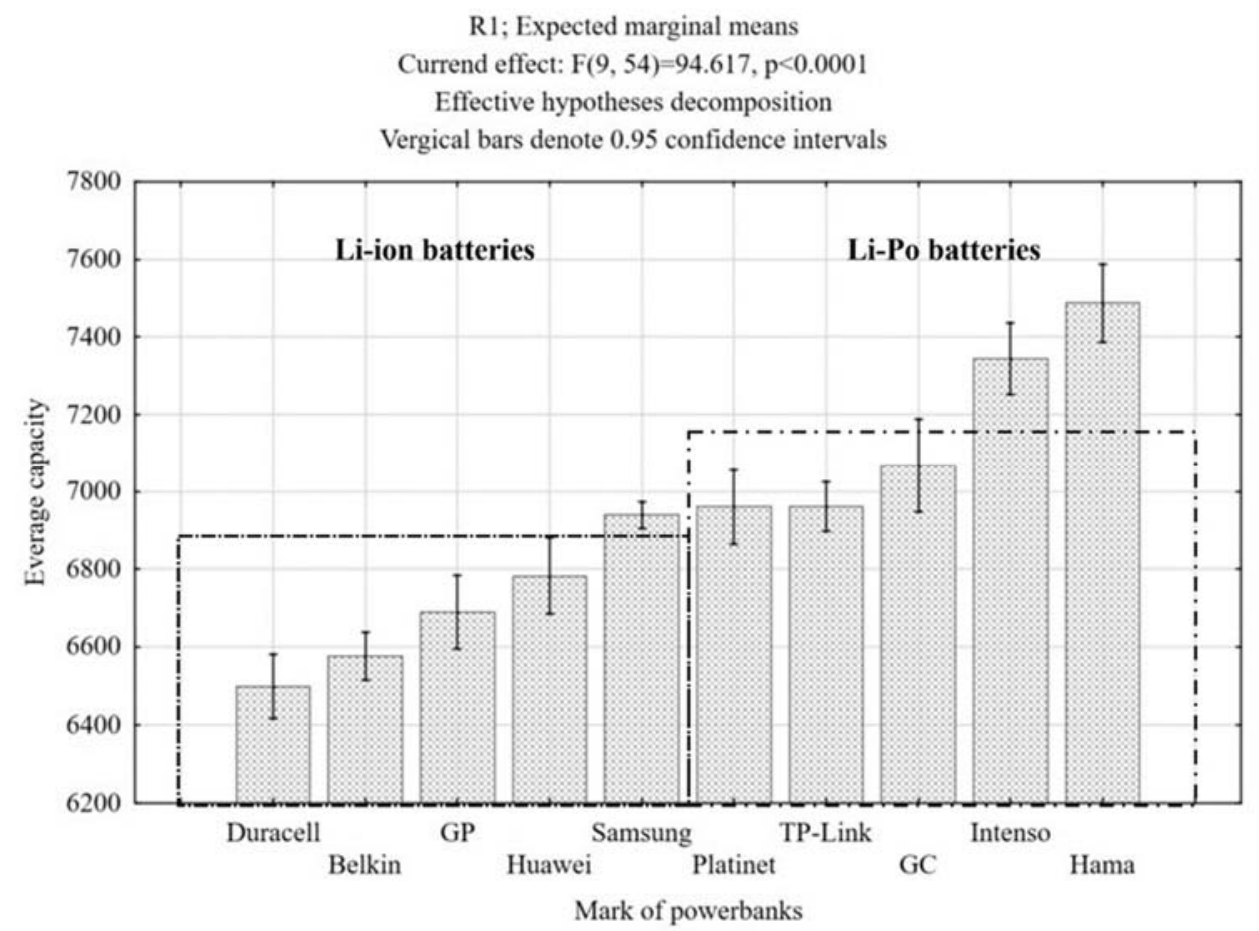

Figure 7. Test results showing average capacities of power banks with Li-ion and Li-Po batteries.

Powerbank charging time at $5 \mathrm{~V}, \mathrm{~h}$

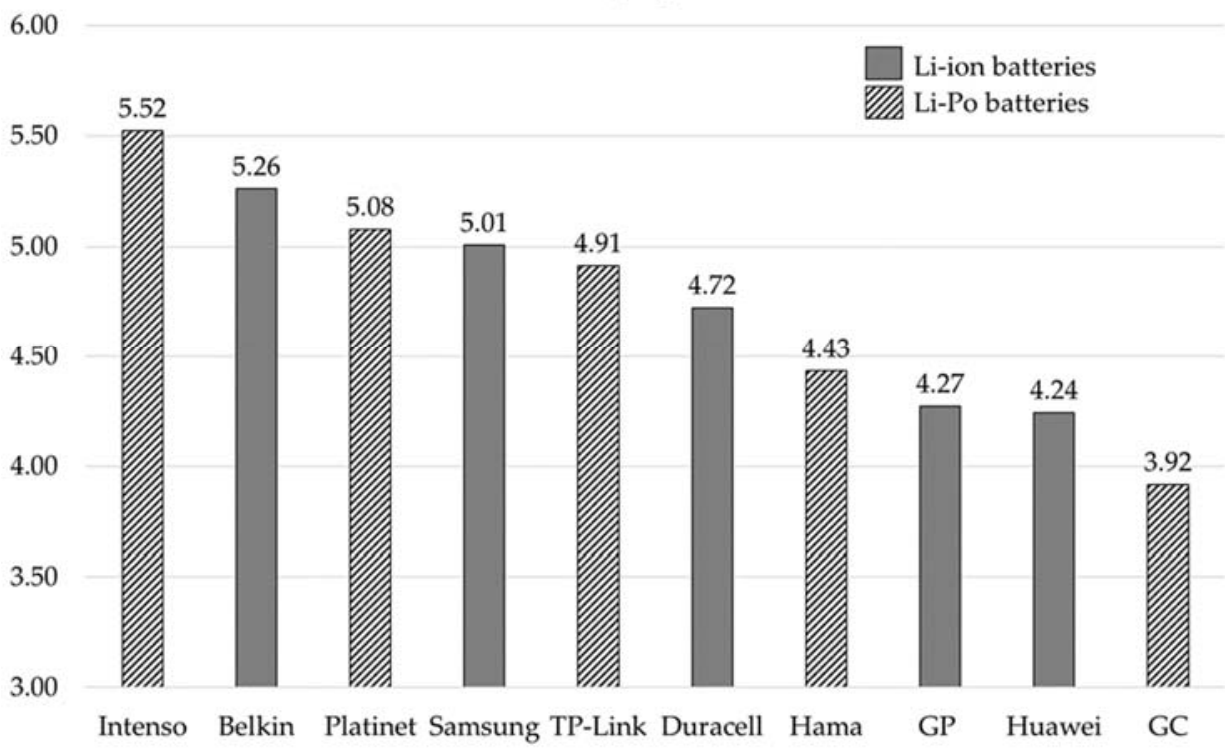

Figure 8. Charging time (in hours) of power banks at $\mathrm{U}=5 \mathrm{~V}$ voltage.

Other determinants that the respondents follow when buying a power bank are the functions of quick charging of target devices from the power bank and the quick charging function of the power bank itself. Among the devices examined, the power banks of four manufacturers had both of these features important for consumers (Table 4). 
Table 4. Comparison of the number of possible discharging and charging modes of power banks ('6.' only standard mode at $5 \mathrm{~V}$, ' + ' possible quick modes at $9 \mathrm{~V}$ or $12 \mathrm{~V}$ ).

\begin{tabular}{|c|c|c|c|c|}
\hline & $\begin{array}{c}\text { Quick Discharge } \\
9 \mathrm{~V}\end{array}$ & $\begin{array}{c}\text { Quick Discharge } \\
12 \mathrm{~V}\end{array}$ & $\begin{array}{c}\text { Quick Charge } \\
9 \mathrm{~V}\end{array}$ & $\begin{array}{c}\text { Quick Charge } \\
12 \mathrm{~V}\end{array}$ \\
\hline Belkin & - & - & - & - \\
\hline Duracell & - & - & - & - \\
\hline GC & + & + & + & + \\
\hline GP & - & - & - & - \\
\hline Hama & - & - & - & - \\
\hline Huawei & + & - & - & - \\
\hline Intenso & - & - & - & - \\
\hline Platinet & - & - & - & - \\
\hline Samsung & + & + & + & + \\
\hline TP-LINK & - & - & - & - \\
\hline
\end{tabular}

Consumers' expectations resulting from the quick discharging and charging function of the power bank obviously concern the time that needs to be spent on charging the target device from the power bank and charging the power bank itself. Further measurements allowed us to verify the charging time of each power bank at a voltage of $U=5 \mathrm{~V}$ (Figure 8) and at a voltage of $U=9 \mathrm{~V}$ (Figure 9), the charging current being automatically set by the tested device. The test results show the average charging times for each device.

Capacity measured with 9V quickcharging, mAh

3800

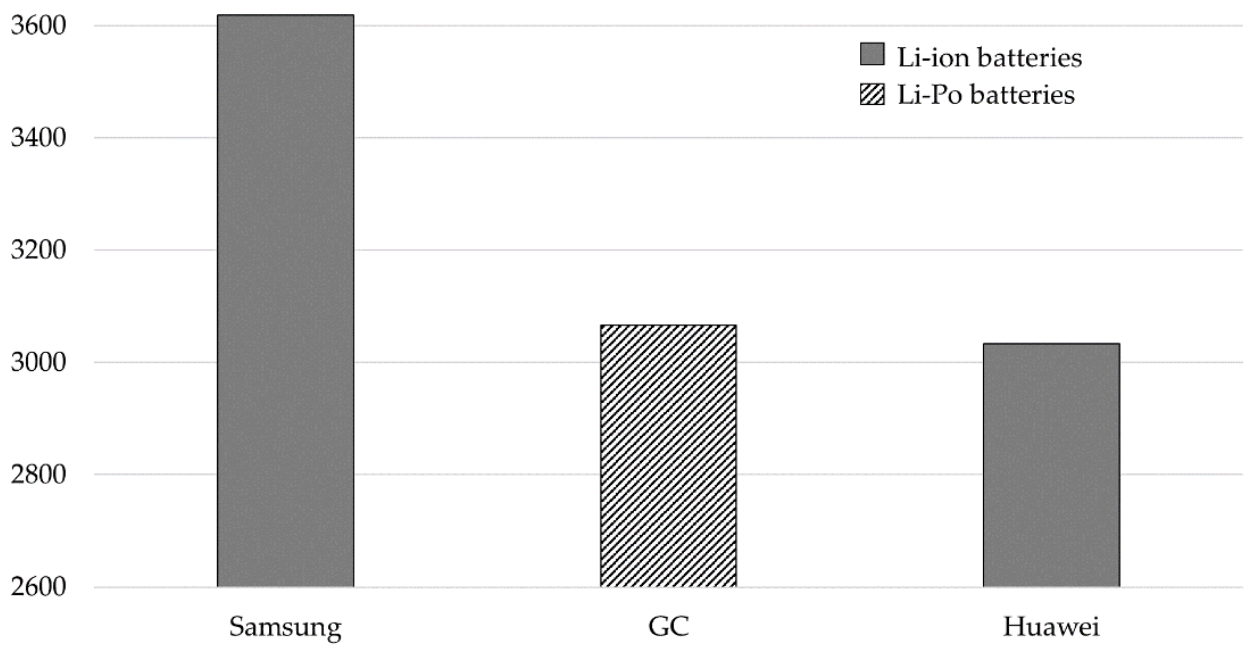

Figure 9. Capacity in $\mathrm{mAh}$ measured with $9 \mathrm{~V}$ quick charging for power banks offering such a function.

Power banks from four manufacturers have the option of so-called quick charging. The charging voltage was $U=9 \mathrm{~V}$, and the charging current was set automatically by the tested device. The test results show the average charging times for each device.

Two of the tested power banks allowed the devices to be charged in the $12 \mathrm{~V}$ quick charging mode. The results of these measurements made it possible to compare the capacity of the power banks with quick discharging (Figure 10). 
Capacity of power banks with quick discharging at $12 \mathrm{~V}, \mathrm{mAh}$

2800
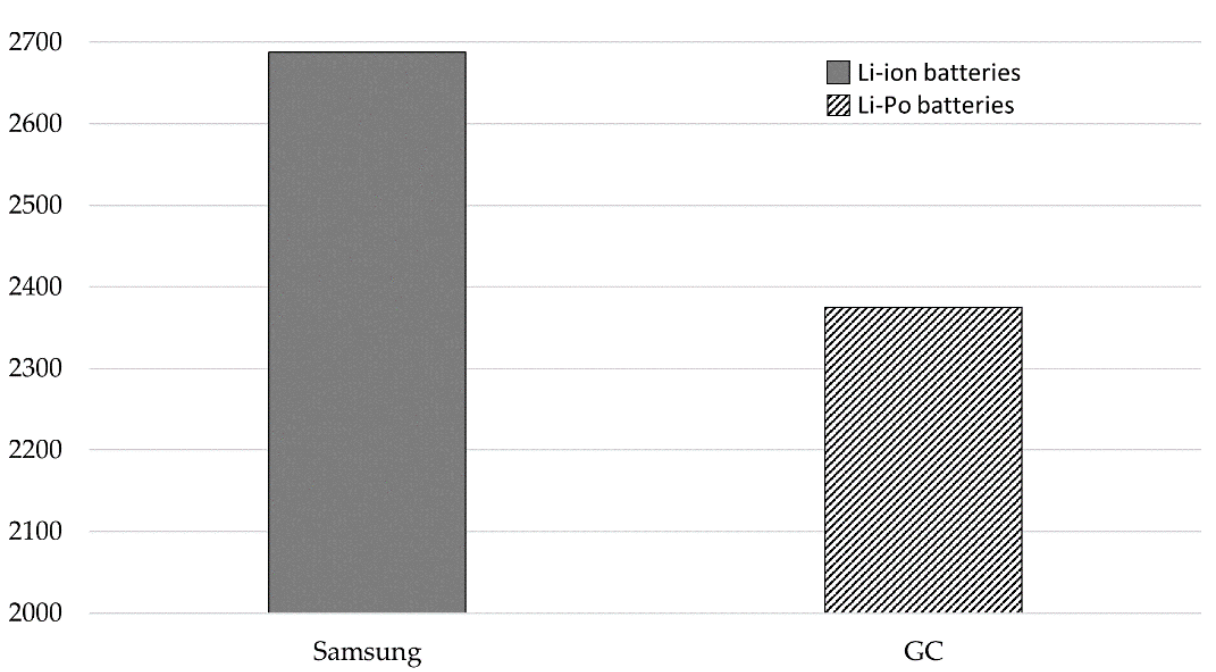

GC

Figure 10. Capacity in $\mathrm{mAh}$ of power banks with quick discharging at a voltage $\mathrm{U}=12 \mathrm{~V}$.

Taking into account the charging time and the usable capacity of the power banks tested under the same conditions at a voltage $U=5 \mathrm{~V}$, a parameter was defined showing the average capacity of a power bank recovered during the charging process in each minute. This parameter, i.e., the ratio of capacity (mAh) to charging time (min), is presented in Table 5.

Table 5. Comparison of capacity, charging time, and the calculated parameter showing the effectiveness of charging the power bank over time.

\begin{tabular}{|c|c|c|c|c|}
\hline & \multirow{2}{*}{$\begin{array}{l}\text { Power Bank Capacity, } \\
\text { mAh }\end{array}$} & \multicolumn{2}{|c|}{ Power Bank Charging Time } & \multirow{2}{*}{$\begin{array}{l}\text { Ratio of Power Bank Capacity and } \\
\text { Its Charging Time, } \mathrm{mAh} / \mathrm{min}\end{array}$} \\
\hline & & h & $\min$ & \\
\hline GC & 7068 & 3.9 & 235 & 30.1 \\
\hline Hama & 7488 & 4.4 & 266 & 28.1 \\
\hline Huawei & 6783 & 4.2 & 255 & 26.6 \\
\hline GP & 6690 & 4.3 & 256 & 26.1 \\
\hline TP-Link & 6961 & 4.9 & 295 & 23.6 \\
\hline Samsung & 6940 & 5.0 & 300 & 23.1 \\
\hline Duracell & 6499 & 4.7 & 283 & 22.9 \\
\hline Platinet & 6961 & 5.1 & 305 & 22.8 \\
\hline Intenso & 7344 & 5.5 & 331 & 22.2 \\
\hline Belkin & 6575 & 5.3 & 316 & 20.8 \\
\hline
\end{tabular}

As illustrated by Table 5 and the above diagram (Figure 11), the speed of the charging process is not determined by the usable capacity of a power bank. There is no visible correlation between these two parameters. If there were a relationship between them, the calculated ratio would be the same or very similar for each power bank. In addition, the specific type of battery (Li-ion and Li-Po) did not indicate any improvement or deterioration of the parameter tested. 
Comparison of power bank capacity and its charging time, $\mathrm{mAh} / \mathrm{min}$

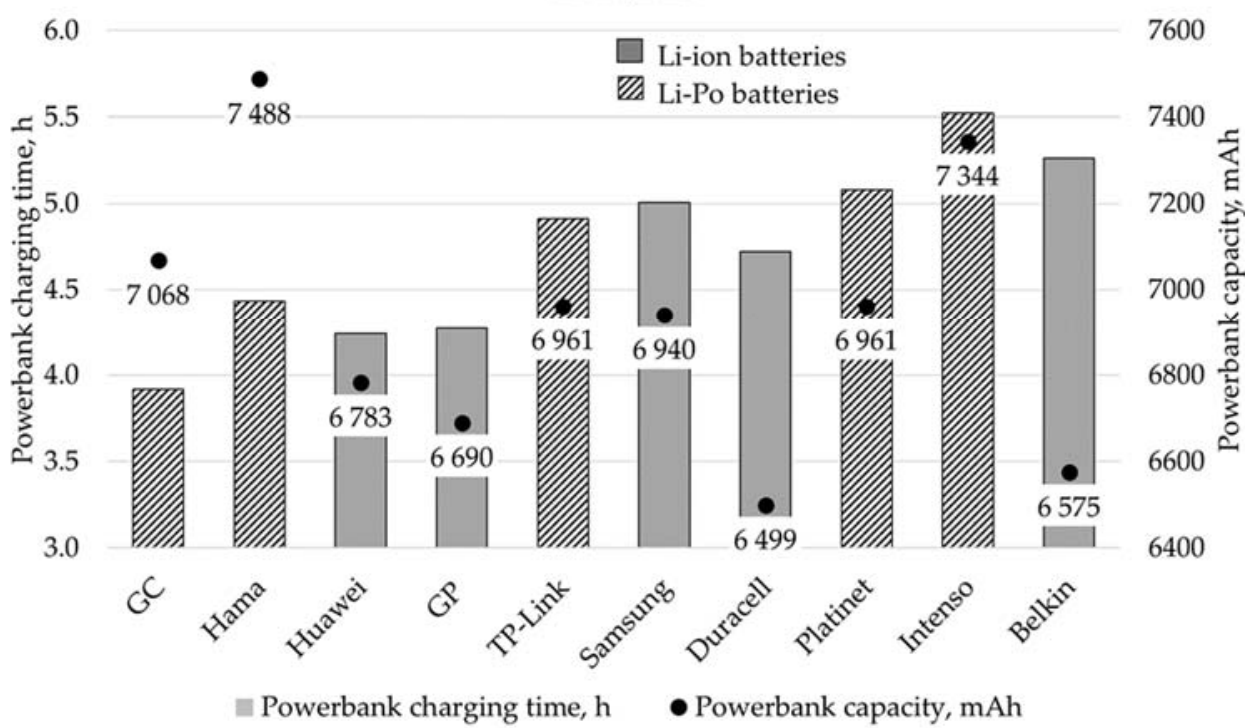

Figure 11. Comparison of power bank capacity and charging time.

Among the respondents, dimensions and weight appeared to be important parameters determining the quality of the power bank. It is about the convenience of use, i.e., minimizing the dimensions of the portable device and reducing its weight. Below are the results of measurements conducted with the aim of determining the ratio of the power bank's capacity to its weight and of establishing the most favorable relationship between these quantities. The tested power banks have a mass in the range of 197-278 g. Differences in the weight of the products may be the result of differences in the mass of the cells inside the power banks, which are responsible for its capacity, but also, for example, of the external material used (housing). The present study allowed us to determine a parameter characterizing the relationship between the power bank's capacity and its mass by calculating the power bank's capacity (mAh)-to-mass ratio (g). For power banks with a low weight in relation to their capacity, this parameter has the highest value. Data on the mass, usable capacity of the power bank, and the calculated discriminant are presented in Table 6.

Table 6. Comparison of masses and calculated values of the parameter describing the relationship between the capacity of a power bank and its weight.

\begin{tabular}{cccc}
\hline Manufacturer & Mass, $\mathbf{g}$ & Capacity, $\mathbf{m A h}$ & Calculated Parameter, $\mathbf{m A h} \mathbf{~ g}{ }^{*}$ \\
\hline Hama & 197.57 & 7488 & 37.90 \\
\hline GC & 196.64 & 7068 & 35.95 \\
\hline Intenso & 204.45 & 7344 & 35.92 \\
\hline Duracell & 188.46 & 6499 & 34.49 \\
\hline Platinet & 204.83 & 6961 & 33.98 \\
\hline TP-Link & 210.16 & 6961 & 33.12 \\
\hline Samsung & 218.63 & 6940 & 31.74 \\
\hline Huawei & 218.97 & 6783 & 30.98 \\
\hline Belkin & 235.76 & 6575 & 27.89 \\
\hline GP & 244.67 & 6690 & 27.34 \\
\hline
\end{tabular}

* Characterizing the relationship between a power bank's capacity and its mass. 
Figure 12 shows the differences in the calculated parameters for individual power banks.

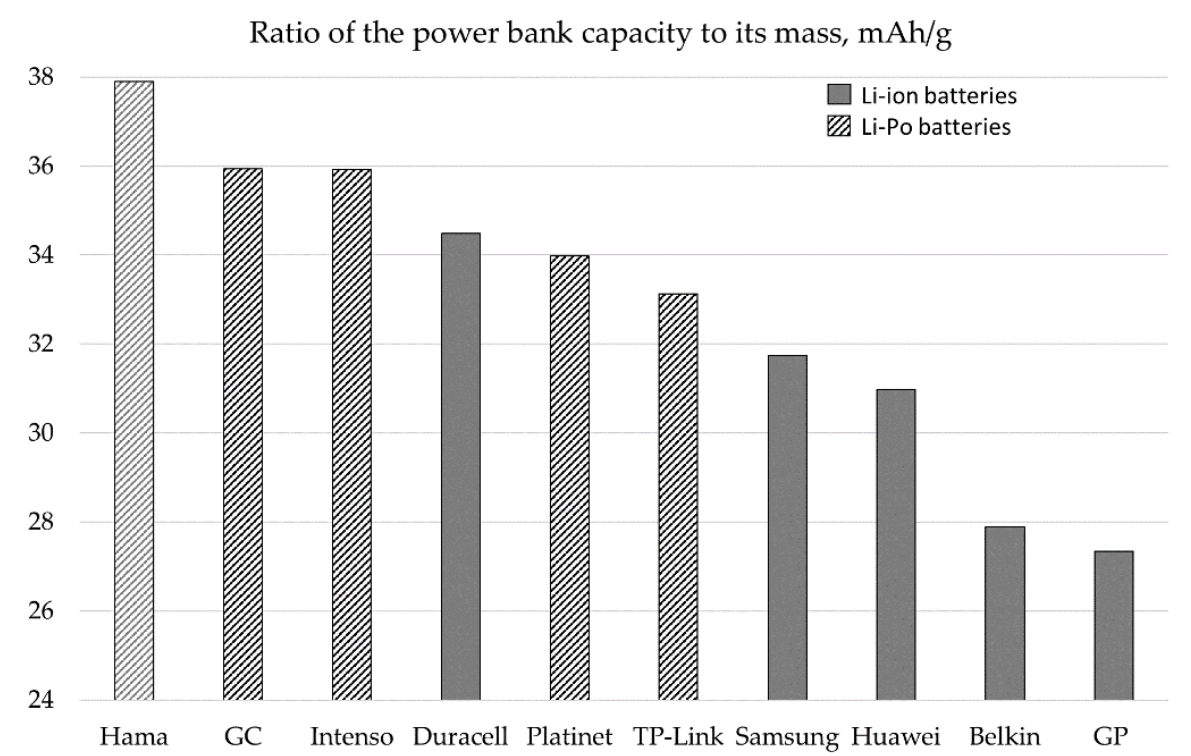

Figure 12. Ratio of the power bank capacity to its mass, $\mathrm{mAh} / \mathrm{g}$.

\section{Conclusions}

On the basis of the results of the survey and the electrical tests of selected power banks, it was found that all manufacturers whose products were covered by the tests indicated on the packaging of their products a capacity under discharge conditions that did not fit the usual conditions of use. That is why the declared capacity of the product is greater than the usable capacity. The results of the present study also show differences between the average capacities of power banks with Li-ion batteries and the technologically newer Li-Po batteries. All Li-Po batteries show greater capacity and total energy. The present study did not reveal any differences between Li-ion and $\mathrm{Li}$-Po batteries in terms of better charging parameters, which would be reflected in the time needed to fully recharge the power bank (up to $100 \%$ capacity).

Based on the results of this research, it was found that just under $50 \%$ of consumers were aware during the purchase that the capacity declared on the power bank packaging was not the capacity that they would actually be able to obtain when using the power bank. More than one-third of the respondents were convinced that this was the capacity they would be able to use when charging, e.g., their phone. Therefore, there is a high probability that these consumers will not be satisfied with the product they buy, because their expectations will not be met. This has its practical consequences, as the users expecting to be able to charge a phone with an average battery capacity of $3000 \mathrm{mAh}$ from a fully charged power bank will only be able to refill their phone's battery twice, instead of obtaining three full charges, and that is with standard charging, at $5 \mathrm{~V}$. If they want to use fast charging, it may, unfortunately, turn out that they will not fully charge their phone even once. For this reason, an important feature of a power bank is the presence of a charge indicator. The results from the first part of this research show that consumers recognize the high importance of this feature.

Dimensions, weight, and strength are physical characteristics that consumers also pay more attention to. Based on the calculated parameter characterizing the relationship between the power bank's capacity and its mass, it was shown that the products of different manufacturers differed despite using batteries with the same capacity. As the customer is interested in the smallest possible weight of the final product and not the battery itself, it can be concluded that the highest possible value of this parameter would be most desirable. The tests did not cover the mechanical properties of the materials used in the battery 
casings, so it is not possible to state how this parameter relates to strength. However, it can be assumed that composite materials, common today, the advantage of which is low specific weight, when put to use in the construction of the power bank housing will enhance its strength and improve the said parameter in comparison with, e.g., metallic materials or classic polymers.

The features that are important from the consumers' perspective also include the price, which was not analyzed in this research, and the quick charging and discharging functions of the power bank. Quick discharge of the power bank allows the faster charging of target devices that have this function. These two features were rated highest in the questionnaire. These functions are important when there is a need to quickly charge or recharge a device, so it is related to the charging/discharging time. Charging times in the standard variant, with a voltage of $5 \mathrm{~V}$, did not differentiate power banks regarding the type of battery. The test results did not show the relationship that one would expect, that the smaller the usable capacity of the power bank, the faster the charging time. Power banks showed large discrepancies here.

The results obtained from the survey also show other properties of power banks important for consumers, which were not covered in this study. These features include design, the ability to charge multiple devices simultaneously, opinions of other users (including those found on the internet), and availability.

Author Contributions: Data curation, A.G.; investigation, J.C.; writing-original draft, P.S. All authors have read and agreed to the published version of the manuscript.

Funding: This research received no external funding.

Institutional Review Board Statement: Not applicable.

Informed Consent Statement: Not applicable.

Data Availability Statement: The data presented in this study are available on request from the corresponding author.

Conflicts of Interest: The authors declare no conflict of interest.

\section{Appendix A}

LSD-Fischer test showing statistical differentiation for analysis concerning important features of a power bank

\begin{tabular}{|c|c|c|c|c|c|c|c|c|}
\hline \multicolumn{9}{|c|}{ NIR test; variable: average score. Probabilities for post hoc tests. Error: between MS =0.89053, df = 1794.0} \\
\hline $\begin{array}{l}\text { Cell } \\
\text { No. }\end{array}$ & R1 & $\{1\} 4.5400$ & $\{2\} 3.4067$ & $\{3\} 4.0567$ & $\{4\} 3.6767$ & $\{5\} 2.6367$ & $\{6\} 3.2400$ & $\{7\} 3.3667$ \\
\hline 1 & Capacity & & 0.000000 & 0.000000 & 0.000000 & 0.000000 & 0.000000 & 0.000000 \\
\hline 2 & Strength & 0.000000 & & 0.000000 & 0.000469 & 0.000000 & 0.030668 & 0.603730 \\
\hline 3 & Carge indicator & 0.000000 & 0.000000 & & 0.000001 & 0.000000 & 0.000000 & 0.000000 \\
\hline 4 & Price & 0.000000 & 0.000469 & 0.000001 & & 0.000000 & 0.000000 & 0.000060 \\
\hline 5 & Design & 0.000000 & 0.000000 & 0.000000 & 0.000000 & & 0.000000 & 0.000000 \\
\hline 6 & Mass & 0.000000 & 0.030668 & 0.000000 & 0.000000 & 0.000000 & & 0.100366 \\
\hline 7 & Dimensions & 0.000000 & 0.603730 & 0.000000 & 0.000060 & 0.000000 & 0.100366 & \\
\hline
\end{tabular}

\section{Appendix B}

LSD-Fischer test showing statistical differentiation for analysis of criteria that respondents follow when buying a power bank 


\begin{tabular}{|c|c|c|c|c|c|c|c|c|c|c|c|}
\hline \multicolumn{12}{|c|}{ JIR test; variable: average score. Probabilities for post hoc tests. Error: between MS = 0.89053, df = 1794.0} \\
\hline $\begin{array}{l}\text { Cell } \\
\text { No }\end{array}$ & $\mathbf{R} 1$ & $\begin{array}{c}\{1\} \\
3.9228 \\
\end{array}$ & $\begin{array}{c}\{2\} \\
2.0000 \\
\end{array}$ & $\begin{array}{c}\{3\} \\
3.6376 \\
\end{array}$ & $\begin{array}{c}\{4\} \\
3.4497 \\
\end{array}$ & $\begin{array}{c}\{5\} \\
3.4899 \\
\end{array}$ & $\begin{array}{c}\{6\} \\
2.8523 \\
\end{array}$ & $\begin{array}{c}\{7\} \\
2.0134 \\
\end{array}$ & $\begin{array}{c}\{8\} \\
3.9899 \\
\end{array}$ & $\begin{array}{c}\{9\} \\
3.6309 \\
\end{array}$ & $\begin{array}{c}\{10\} \\
4.0738\end{array}$ \\
\hline 1 & A & & & 0.000520 & 0.000000 & 0.000000 & 0.000000 & 0.000000 & 0.413721 & 0.000383 & 0.065974 \\
\hline 2 & B & 0.000000 & & 0.000000 & 0.000000 & 0.000000 & 0.000000 & 0.870139 & 0.000000 & 0.000000 & 0.000000 \\
\hline 3 & C & 0.000520 & 0.000000 & & 2159 & 0.072214 & 0.000000 & 0.000000 & 0.000018 & 0.934852 & 0.000000 \\
\hline 4 & $\mathrm{D}$ & 0.000000 & 0.000000 & 0.022159 & & 0.6 & 0.000000 & 0.000000 & 0.000000 & 0.027383 & 0.000000 \\
\hline 5 & $\mathrm{E}$ & 0.000000 & 0.000000 & 0.072214 & 0.623824 & & 0.000000 & 0.000000 & 0.000000 & 0.086144 & 0.000000 \\
\hline 6 & $\mathrm{~F}$ & 0.000000 & 0.000000 & 0.000000 & 0.000000 & 0.000000 & & 0.000000 & 0.000000 & 0.000000 & 0.000000 \\
\hline 7 & G & 0.000000 & 0.870139 & 0.000000 & 0.000000 & 0.000000 & 0.000000 & & 0.000000 & 0.000000 & 0.000000 \\
\hline 8 & $\mathrm{H}$ & 0.413721 & 0.000000 & 0.000018 & 0.000000 & 0.000000 & 0.000000 & 0.000000 & & 0.000013 & 0.306938 \\
\hline 9 & $\mathrm{I}$ & 0.000383 & 0.000000 & 0.934852 & 0.027383 & 0.086144 & 0.000000 & 0.000000 & 0.000013 & & 0.000000 \\
\hline 10 & $\mathrm{~J}$ & 0.065974 & 0.000000 & 0.000000 & 0.000000 & 0.000000 & 0.000000 & 0.000000 & 0.306938 & 0.000000 & \\
\hline
\end{tabular}

\section{References}

1. Forbes. Available online: https://www.forbes.pl/biznes/ilu-ludzi-posiada-smartfona-dane-na-2017-i-2018-rok/mhb6djb (accessed on 5 June 2021).

2. Silver, L. Smartphone Ownership Is Growing Rapidly around the World, but Not Always Equally; Pew Research Center: Washington, DC, USA, 2019; Available online: https:/ /www.pewresearch.org/global/2019/02/05/smartphone-ownership-is-growing-rapidlyaround-the-world-but-not-always-equally / (accessed on 10 June 2021).

3. Mobirank. Available online: https://mobirank.pl/2020/01/31/raport-digital-i-mobile-na-swiecie-w-2020-roku/ (accessed on 9 June 2021).

4. GlobalWebIndexQ3. Available online: https://libranda.com/wpcontent/uploads/2019/07/Repoon_devices_ownership_uage_ July2019.pdf (accessed on 11 May 2021).

5. Vilhelmson, B.; Thulin, E.; Elldér, E. Where does time spent on the Internet come from? Tracing the influence of information and communications technology use on daily activities. Inf. Commun. Soc. 2016, 20, 1-14. [CrossRef]

6. López-Sintas, J.; López, P.; Lamberti, G. Socially Patterned Strategic Complementarity between Offline Leisure Activities and Internet Practices among Young People. Leis. Sci. 2020, 1-22. [CrossRef]

7. Directive 2014/30/EU of the European Parliament and of the Council of 26 February 2014 on the Harmonisation of the Laws of the Member States Relating to Electromagnetic Compatibility (Recast). Available online: https:/ / eur-lex.europa.eu/legalcontent/EN/TXT/PDF/?uri=CELEX:32014L0030\&rid=4 (accessed on 11 June 2021).

8. Directive 2011/65/EU of the European Parliament and of the Council of 8 June 2011 on the Restriction of the Use of Certain Hazardous Substances in Electrical and Electronic Equipment. Text with EEA Relevance. Available online: https:/ / eur-lex. europa.eu/legal-content/en/TXT/?uri=CELEX:32011L0065 (accessed on 11 June 2021).

9. Act of 13 April 2016 on Conformity Assessment and Market Surveillance Systems, Article 88 and 89 (Journal of Laws of 2016, Item 542). Available online: http://isap.sejm.gov.pl/isap.nsf/download.xsp/WDU20160000542/U/D20160542Lj.pdf (accessed on 15 June 2021). (In Polish)

10. MIL-STD 810F 516.5-Defense Standard (Military Standard), US Army Military Standard, Environmental Engineering Considerations and Laboratory Tests. Available online: https:/ /www.atec.army.mil/publications/mil-std-810f/milstd810f.pdf (accessed on 25 March 2021).

11. Geng, Y.; Sarkis, J.; Bleischwitz, R. How to globalize the circular economy. Nat. Comment 2019, 565, 153-155. [CrossRef] [PubMed]

12. Li, H.; Dai, J.; Wang, A.; Zhao, S.; Ye, H.; Zhang, J. Recycling and Treatment of Waste Batteries. IOP Conf. Ser. Mater. Sci. Eng. 2019, 612, 052020. [CrossRef]

13. Deng, D. Li-ion batteries: Basics, progress, and challenges. Energy Sci. Eng. 2015, 3, 385-418. [CrossRef]

14. Schröder, R.; Aydemir, M.; Seliger, G. Comparatively Assessing different Shapes of Lithium-ion Battery Cells. Procedia Manuf. 2017, 8, 104-111. [CrossRef]

15. Diao, W.; Saxena, S.; Pecht, M.G. Analysis of Specified Capacity in Power Banks. IEEE Access 2020, 8, 21326-21332. [CrossRef]

16. Sparkfun. Available online: https:/ / learn.sparkfun.com/tutorials/battery-technologies (accessed on 28 February 2021).

17. Sazhin, S.; Dufek, E.J.; Gerin, K.L. Enhancing Li-Ion Battery Safety by Early Detection of Nascent Internal Shorts. J. Electrochem. Soc. 2017, 164, A6281-A6287. [CrossRef]

18. Barcellona, S.; Brenna, M.; Foiadelli, F.; Longo, M.; Piegari, L. Analysis of Ageing Effect on Li-Polymer Batteries. Sci. World J. 2015, 2015, 8. [CrossRef] [PubMed] 